Philosophy and Progress: Vols. LV-LVI, January-June, July-December, 2014 ISSN 1607-2278 (Print), DOI : http://dx.doi.org/10.3329/pp.v55i1-2.26394

\section{A STUDY ON CONSUMERS' PSYCHOLOGY ON MARKETING TOOLS}

\section{Md. Samiul Hasan Babu*}

\begin{abstract}
In this twenty first century, market became more competitive and existing players have to fight in the ocean and have to survive after sacrificing own blood. However, every market players wants to live in the blue ocean. Thus, they attempt to develop and market the right product for right consumers. However, this is most important to understand how consumers define their need and how they want to meet their needs. It is important to understand the difference which one is need for which customer and which one want or demand to whom. In this stage, it raises the question to have better a deep insight about consumers' psychology. If a marketer can understand his/her consumers' psychology, he/she might easily pick up the best weapon to hit the consumers and to get them into the spider net spread to catch them all. Today, consumers are very much informative and they know well what they want and what is going on. So, marketers need to be very careful in designing marketing strategy to offer the best brand with a sense to deliver the message or
\end{abstract}

\footnotetext{
* Researcher \& Executive Officer, Mercantile Bank Limited, Dhaka E-mail : msamiulhasan@gmail.com
}

communicating the consumer about the brand without bothering or irritating the consumer. Creating the best brand depends on how well a marketer can read consumers' mind regarding the requirement and final success depends on how well they could communicate them through different marketing techniques/tools. These all require a good sense of consumer psychology for the marketers to draw a perfect image of the consumers in their marketing strategy development. The marketing techniques used by all marketers to attract consumers, produce new product, attract through different activities like coupon, demonstration, event show, trade show, advertising, celebrity endorsement are almost same. However, success run behind the winner who can better adopt consumers' psychology.

Key Words: Consumer Psychology, Marketing techniques, consumer behavior.

\section{INTRODUCTION}

\subsection{Background}

In today's busy life, marketing activities are the main source of getting in touch with target customers and provide them the correct and important information. Any type of business can be benefited by using the proper promotional tools. Marketers use different modes of promotion and advertising in order to satisfy customer and meet up their respective demands. Marketing activities, which mean sources of communication or promotion that, cover all types of market. It includes Billboards, Banners, in store display, Word of mouth, Advertising, public relation, direct marketing, trade show, product placement and entertainmentetc. Marketing activities are effect consumer's mind because they think of it when they saw the activities of the promotional tools. It is used to communicate with the consumers so the area of communication is huge and it is easy to reach target customers with the help of different marketing strategy. 
Different promotional tools have effect on consumer's psychology, like: consumers are different from one to another. The psychology of consumer about brand and retailers are very important for buying different product. And consumers always want something easy and less time consuming strategy which made their life easy in their busy life. So here promotional tools like direct selling, personal selling, advertisement, billboard, word of mouth help consumer to find out their desire product. Because different organizations provide their promotional tools in different ways. So it is easy for consumer to take decision between different alternative.

Culture is an important combination of character, behavior and a self-identification of human being, these characteristics help an individual to create his or her own buying behavior, and however, isolating culture as a variable that can be studied and readily implanted is very difficult, taking into consideration that the buying behaviors of human beings consist of three phases which are the individual, societal and situational. So organizations are applying promotional tools very tactfully without hurting any one’s own culture.

One of the most basic desires of a company is to provide information about a product to potential consumers. Tools available to an organization for informing potential consumers about a product include billboards, flyers, Internet Web sites, magazines, newspapers, radio spots, and television commercials. Normally a variety of these promotional tools are used to communicate a single, coordinated message to potential consumers. These different promotional tools can provide potential consumers with an array of information about a product, such as features, quality, and/or price. The informational focus depends on the makeup of the target audience that the company is trying to reach with its message.
When consumers view a commercial and believe that the celebrity endorser and the brand "match up," recall of the campaign and impact of the advertisement increase. In this sense, if a celebrity endorser seems out of place in a campaign, the impact won't be nearly as powerful. So it is attractive for a consumer and also motivation. Because people are follow celebrity as their ideal. When the celebrity uses those product consumers are motivated by them.

Businesses need to inform customers of the products and services they provide in order to facilitate the firm's survival in the very competitive business environment. In addition, effective communication with customers is vital to ensure that business generates sales and profits.

\subsection{Statement of the Problem}

This study attempted to analyze consumer psychology regarding different marketing techniques used by the marketers to reach their messages to the target consumers.

\subsection{Objective of the Study \\ Broad Objective}

To analyze consumer psychology regarding different marketing activities use by the marketers.

\section{Specific Objective}

1. To identify the factors that influence consumer's psychology.

2. To measure the relative impact of each promotional tools on consumer.

3. To identify how consumer views different marketing activities. 


\subsection{Research Implications}

The present study may also have the traditional limitations associated with survey research such as selection error, measurement error, non-response error. Since the study was limited to 100 respondents and the respondent were from Dhaka, findings can only be used as a guide for further research into this area.

\subsection{Limitations of the Study}

The study is limited in its scopes due to time and resources constrains. Moreover, the researcher found that respondents are not very much interested to give their time while they have to answer the questions after taking some time for thinking over it. Finally, the researcher found that some respondents got confused over rational versus emotional aspects of different marketing tools used by marketers.

\section{LITERATURE REVIEW}

In this era of competitive market, marketers are working hard to adapt and improve their marketing campaigns and marketing strategies in persuasion of effectively reaching maximum numbers of target consumer. However, their first and foremost challenge is to understand consumers' psychology; how the consumers define their need, how do they want to meet their needs, wants or demands, how consumers think, feel, reason, and between different alternatives (e.g., brands, products, and retailers), how the consumer is influenced by his or her environment (e.g., culture, family, signs, media), or how do they perceive marketers offers towards their ultimate solutions. It is all about a game with consumers philosophy i.e., how they act or behave against marketers offer, way of interpreting and/or available offers or options and understanding their psychology. Thus, a study of psychology especially consumer psychology has become more important for marketers. In the early studies, researchers define psychology as the scientific study of human behavior and mental processes. It is the behaviorist views that are purely objective and experimental branch of natural science and its theoretical goal is the prediction and control of behavior (Paquette, 2013).

Consumer psychology is the study of why people buy things. Psychologists try to find the underlying cognitive processes that explain consumers' choices and how they respond to the influence of marketing, as well as the external stimuli that convince people to purchase certain items. Consumer psychologists examine the preferences, customs, and habits of various consumer groups; their research on consumer attitudes is often used to help design advertising campaigns and to formulate new products. Cognitive theories have dominated the field of consumer psychology for long time ago. However the observed lack of consistency between attitude and behavior has suggested the need of investigation more thoroughly situational and behavioral variables. Consumer psychology analysis viewed as an alternative situational variable and measure of behavior (Foxall, Goldsmith and Brown, 1998).

An alternative approach to consumer behavior that emphasizes the influence of the situational variables and direct measures of behavior might be found in behavioral psychology. Consumer psychology as a field as usually known, has developed a coherent and systematic set of theoretical concepts, derived from a long tradition of experimental and applied research. It has always emphasized the role of situational variables in the determination of behavior playing particular attention to events that antecede and follow individual responding and has defended the adoption direct measures of behavior with little use of hypothetical constructs in its theory. 
Now marketers are more active to satisfy the consumers and want to retain them due to high competition. That is the reason why marketers are using different marketing promotional activities to reach their messages to their market. However, a marketer must have clear idea about consumer psychology. If marketers use marketing promotional activities without analyzing consumer psychology, the customer may not like these activities or proper messages may not be delivered to target market. Further, marketing across cultural boundaries is a difficult and challenging task. The success of global marketers depends on how well they understand and adapt to consumer's psychology.

\subsection{Impact of Marketing Activities on Consumer Psychology}

An increase of marketing activities requires organizations to attract and retain customers to ensure a sustainable competitive advantage. To achieve this objective, organizations must focus their efforts on developing and sustaining an organizational culture that emphasizes internal customer well-being as a means to attract and retain consumer. The key concept of marketing is customer centrality: marketers cannot ignore customer decision-making. Understanding the processes involved in making those decisions is central to establishing policy. Thus, modish marketers invest a lion share of their time and money to understand consumer behavior and industrial buyer behavior.

The impact of marketing activities on consumer is huge especially for promotional activities and new product. Because organizations conduct extensive study when they launch new product or introduce new promotional activities. When organizations launch something new in their product line, at first they attempt to create an impact on consumers and promotional activities are tools to do so. Depending on target consumers' psychology and behavioral perspective, organizations choose their promotional activities very carefully. However, marketers are integrating different promotional tools to create a multifaceted impact on consumers.

In early 1900s scholars began to explain how psychological principles could be applied by advertiser and marketer. In 1939, Viennese psychologist Ernest conducted motivation research, a research methodology, he initiated to use Frud's psychoanalytic techniques to uncover the hidden motivations of customer, which were essentially qualitative and subjective in nature. In the 1950's Dichter's researchers with which he adopted the brilliant ideas from the Freduian Psychology were popularized and widely used by motivation and consumer researchers, and employed by advertisers.

Psychological reason in understanding the consumer behavior is to enable marketers and advertises to know how consumer would react to product, service, advertising and promotion and to understand why they would make their buying decision. Therefore, it is imperative upon marketing and advertising researchers to include psychodynamic concepts and theories for an effective implementation of promotional message and marketing strategies. The articulation of psychodynamic aspects such as mental, attitude, motivational and instinctive process acts as a converging point of transformation of the consumer.

Lifestyle of the consumers is so vital in understanding how and why consumers behave as they do. Their lifestyle is how they live. It includes the product they purchase, how they consume, what they think and how they feel toward them. This is the function of the consumer self-concept. Self-concept is the 
product of experience as a result of the individual growth process and their personal socio environment.

Consumer psychology refers to the selection, purchase and consumption of goods and services for the satisfaction of wants. There are different processes involved in the consumer behavior. Initially the consumer tries to find what commodities he would like to consume, then he selects only those commodities that promise greater utility. After selecting the commodities, the consumer makes an estimate of the available money which he can spend. Lastly, the consumer analyzes the prevailing prices of commodities and takes the decision about the commodities he should consume.

\subsection{Impact of Marketing Mix on Consumer Psychology}

To understand the responses of consumers toward marketing activities, consumers buying decision is the central point of the marketer's effort. Consumer behavior is complex and ever changing. What a customer buys is not good enough, the reasons of buying are more important. According to Okoroafo (2009), to build a successful guideline for increasing sales and promoting positive customer relationships, the marketers must analyze why customers buy and the factors which motivate them to buy.

Marketing mix is a set of marketing tools that are blended to produce the response the organization want from the target market. According Kotler and Keller (2011), influencing factors for purchasing behavior are marketing mix \& personal characteristics. Okoroafo (2009), indicates marketing mix has a strong relationship with consumers buying patterns, brand choices and incidences of purchase. According to Kotler and Keller (2011), many consumers use price as an indication of the quality of the brand which is an important factor in purchasing decision. Place or the distribution channel is a combination of institutions through which a seller market product to use or ultimate consumer (Mughal et al., 2014). Different kind of promotional activities are essential in modern marketing to keep and grow the market share. Successful sales promotions have to be consistent with the brand valus and to be consistent with all other aspects of the brand.

Most of the studies have shown that the factors of marketing mix have a relationship on the purchasing behavior of the consumer. To attain the consumers mind share, he proper arrangement of the marketing mix is essential. Most of the studies have shown that the factors of marketing mix have a relationship on consumer psychology.

\section{METHODOLOGY}

In this study, researcher conducted a qualitative research to properly identify the problem by using secondary data from different sources i.e. information from various publications, journals, websites, etc. After, getting an in-depth view of the problem, a descriptive research was conducted to find out factors that affect consumers' perception regarding marketing activities of different companies to attract consumers. In this regard, impact of different tools like coupon, free gift, free sample, display in store, online recommendation, positive word of mouth, trade show, sponsorship, demonstration, sms notifications, liflets, celebrity endorsement, advertisement through TV, radio, and outside advertisement like billboard, festoons, signboards used by marketers to attract consumers' concentration were needed to determine. In order to pursue consumers' response to marketer's activity, these aforementioned factors were also examined to look for whether they contribute in a positive manner.

Researcher of this study collected quantitative data from direct consumers through a survey to understand their perception 
regarding different marketing activities and promotional tools used by companies. Metric scaled data on variables was required for this study. Therefore, a non-comparative scaling technique (see detail in scaling technique) was applied in this study. A questionnaire using 7 point likert scale was designed to collect data from 100 respondents. Data were analyzed by using Statistical Package for the Social Sciences (SPSS).

\subsection{ANALYSIS AND INTERPRETATION}

\subsection{Sample Profile:}

The respondents were selected from different age group with different education level which included $56 \%$ male and $44 \%$ female. Among the respondents, $4 \%$ were under 15 , 51\% were between 15 to 29 years, 25\% were between 30 to 44 years, $17 \%$ were between 45 to 29 years, 3\% were over 60 years. On the other hand, on the educational background, $6 \%$ of respondents were of SSC level, 5\% were of HSC level, 36\% were under graduate, $47 \%$ were post graduate, and $6 \%$ were of other background. On the occupational ground $36 \%$ of respondents were students, $24 \%$ were government employees, $23 \%$ were private employees, $15 \%$ were businesspersons, and rest were from other sectors.

\subsection{Reliability Test}

For Reliability Test, marketing activities have been divided into following five categories:

\begin{tabular}{|l|c|c|}
\hline \multicolumn{1}{|c|}{ Variables } & $\begin{array}{c}\text { Number of } \\
\text { items }\end{array}$ & Cronbach's alpha \\
\hline Customer Loyalty & 6 & .723 \\
\hline Entertainment & 5 & .663 \\
\hline Brand Promotion & 6 & .763 \\
\hline Trust & 5 & .646 \\
\hline Perceived value & 5 & .655 \\
\hline
\end{tabular}

The data were first tested for using Cronbach's alpha to assess reliability. Internal consistency (reliability) values measurement items were assessed before entering into the structural analysis. The Cornbach's of the variables are among 0.646 to 0.723 that means all the variables have internal consistency. The test reveals that customer loyalty has $72.3 \%$ consistency among each other, entertainment has 66.3\%, and brand promotion has $76.3 \%$ consistency. Trust and perceived value has $64.6 \%$ and $65.5 \%$ consistency among each other respectively.

\subsection{Regression Analysis}

\subsubsection{Model Summary}

The value of $\mathrm{R}$ square (.881) and $\mathrm{R}$ (.890), from Table-1, predicting a strong relationship between the set of independent variables and dependent variable with the standard error of 7.399 percent. That means the consumer psychology regarding marketing activities is $98 \%$ influenced by brand loyalty, entertainment, brand promotion, trust and perceived value. The rest $2 \%$ are influenced by some other factors that might have less or no influence on consumer psychology or might have not been considered in this study.

Table - 1

\section{Regression Model Summary}

\begin{tabular}{|c|c|c|c|c|}
\hline Model & $\mathrm{R}$ & R Square & $\begin{array}{c}\text { Adjusted R } \\
\text { Square }\end{array}$ & $\begin{array}{c}\text { Std. Error of } \\
\text { the Estimate }\end{array}$ \\
\hline 1 & $0.890^{\text {(a) }}$ & 0.881 & 0.980 & 0.7399 \\
\hline
\end{tabular}

(a) Predictors: (Constant), Brand loyalty, entertainment, trust, perceived value, brand promotion 


\subsubsection{Significance Testing}

In this study, a test has been conducted to test the significance of the overall regression equation and specific partial regression coefficients. Table -2 shows the level of significance of the overall regression equation:

Table - 2

Significance testing for overall regression model

\begin{tabular}{|c|c|c|c|c|c|c|}
\hline \multicolumn{7}{|c|}{ ANOVA $^{(\mathrm{b})}$} \\
\hline \multirow{2}{*}{ Model } & $\begin{array}{c}\text { Sum of } \\
\text { Squares }\end{array}$ & Df & $\begin{array}{c}\text { Mean } \\
\text { Square }\end{array}$ & F & Sig. \\
\hline 1 & Regression & 54.132 & 5 & 10.826 & $\begin{array}{c}1.977 \\
\text { E3 }\end{array}$ & $\begin{array}{c}.000 \\
\text { (a) }\end{array}$ \\
\cline { 2 - 8 } & Residual & 1.062 & 194 & .005 & & \\
\cline { 2 - 8 } & Total & 55.194 & 199 & & & \\
\hline
\end{tabular}

a. Predictors: (Constant), Brand loyality, entertainment, trust, perceived value, brand promotion.

b. Dependent Variable: DV (Consumer psychology).

The $\mathrm{F}$ value of the test for the data is 1.977E3. The study shows that there's a positive significant impact of these independent variables on the dependent variable and the model applied is significantly good enough in predicting the dependent variable.

\subsection{Crosstab Analysis}

Bivariate cross-tabulation describes two categorical variables simultaneously in a table that reflects the joint distribution of two or more variables (Malhotra, 2008, p. 469). In this study, the researcher attempted to analyze the impact of marketing tools used by marketers on different categorical variables like occupation, age, education, gender.

Table- 3 shows that $75 \%$ of government employees and $30.40 \%$ of private employees strongly agreed that sponsorship create a positive impact on consumer mind. $60.9 \%$ of private employees and $16.7 \%$ government employees agreed and $8.7 \%$ private employees disagreed that sponsorship create a positive impact on brand promotion. So in case of sponsorship private and government employee should get the first priority of target market.

\section{Table-3}

\section{Occupation * Sponsorship create a positive impact on consumer mind Crosstabulation}

\section{\% within Occupation}

\begin{tabular}{|l|l|l|l|l|l|l|}
\hline \multirow{2}{*}{ Occupation } & \multicolumn{5}{|c|}{ Sponsorship create a positive impact on } & \multirow{2}{*}{ Total } \\
\cline { 2 - 6 } & $\begin{array}{l}\text { Strongly } \\
\text { Disagree }\end{array}$ & Disagree & Neutral & Agree & $\begin{array}{l}\text { Strongly } \\
\text { Agree }\end{array}$ & \\
\hline Student & & $2.8 \%$ & $22.2 \%$ & $25.0 \%$ & $50.0 \%$ & $100.0 \%$ \\
\hline $\begin{array}{l}\text { Government } \\
\text { employee }\end{array}$ & & & $8.3 \%$ & $16.7 \%$ & $75.0 \%$ & $100.0 \%$ \\
\hline $\begin{array}{l}\text { Private } \\
\text { employee }\end{array}$ & $8.7 \%$ & & & $60.9 \%$ & $30.4 \%$ & $100.0 \%$ \\
\hline $\begin{array}{l}\text { Business } \\
\text { Others }\end{array}$ & & & & $53.3 \%$ & $46.7 \%$ & $100.0 \%$ \\
\hline Total & $2.0 \%$ & $1.0 \%$ & $10.0 \%$ & $37.0 \%$ & $50.0 \%$ & $100.0 \%$ \\
\hline
\end{tabular}


Table- 4 shows that $58.30 \%$ of government employees and $66 \%$ of businesspersons strongly agreed on that 'door to door selling saves their time'. $41 \%$ of the students and $62 \%$ private employees agreed on the same condition. 25\% of government employees and $16.7 \%$ of students disagreed to the fact of time saving through door to door selling. Thus, it is convenient to or supportive to government employees and businesspersons to save their time through door to door selling and accordingly, when marketers go for door to door selling their target should be job holders.

Table-4

Occupation* Door to Door Selling has benefited me in case of time saving Crosstabulation

$\%$ within Occupation

\begin{tabular}{|l|l|l|l|l|l|l|}
\hline \multirow{2}{*}{ Occupation } & \multicolumn{5}{|c|}{$\begin{array}{l}\text { Door to Door Selling has benefited me in case } \\
\text { of time saving }\end{array}$} & \multirow{2}{*}{ Total } \\
\cline { 2 - 7 } & $\begin{array}{l}\text { Strongly } \\
\text { Disagree }\end{array}$ & Disagree & Neutral & Agree & $\begin{array}{l}\text { Strongly } \\
\text { Agree }\end{array}$ & \\
\hline Student & $16.7 \%$ & $16.7 \%$ & $11.1 \%$ & $41.7 \%$ & $13.9 \%$ & $100.0 \%$ \\
\hline $\begin{array}{l}\text { Government } \\
\text { employee }\end{array}$ & $12.5 \%$ & $25.0 \%$ & & $4.2 \%$ & $58.3 \%$ & $100.0 \%$ \\
\hline $\begin{array}{l}\text { Private } \\
\text { employee }\end{array}$ & $13.0 \%$ & $4.3 \%$ & $8.7 \%$ & $65.2 \%$ & $8.7 \%$ & $100.0 \%$ \\
\hline Business & & $13.3 \%$ & $6.7 \%$ & $13.3 \%$ & $66.7 \%$ & $100.0 \%$ \\
\hline Others & $12.0 \%$ & $15.0 \%$ & $7.0 \%$ & $33.0 \%$ & $33.0 \%$ & $100.0 \%$ \\
\hline Total & & & & & $100.0 \%$ & $100.0 \%$ \\
\hline
\end{tabular}

SPSS Output

Table- 5 reveals that respondents under the age group of 15 to $29,15.70 \%$ strongly agreed that online recommendations are helpful to provide important information regarding a brand. $51 \%$ of the same age group and $32 \%$ of the age group of 30 years to 44 years agreed that online recommendation provides important information. People over 60 years of old are neutral on this ground. On the other hand, $64.7 \%$ of the respondents of age group of 45 years to 59 years and $33.3 \%$ of respondents over 60 years disagreed on that online recommendation provide important information. So, marketers should attempt to access customers with age group ranging from 15 years to 44 years in order to reach with more target customers through providing online recommendations regarding their brand.

Table-5:

\section{Age * Online recommendation provides details and important information Cross tabulation}

\begin{tabular}{|c|c|c|c|c|c|c|c|}
\hline & & \multicolumn{5}{|c|}{$\begin{array}{l}\text { Online recommendation provides details } \\
\text { and important information }\end{array}$} & \multirow[b]{2}{*}{ Total } \\
\hline & & $\begin{array}{l}\text { Strongly } \\
\text { Disagree }\end{array}$ & Disagree & Neutral & Agree & $\begin{array}{l}\text { Strongly } \\
\text { Agree }\end{array}$ & \\
\hline \multirow[t]{5}{*}{ Age } & $\begin{array}{l}\text { Below } 15 \\
\text { years }\end{array}$ & & $25.0 \%$ & & $75.0 \%$ & & $100.0 \%$ \\
\hline & 15 to 29 & & $9.8 \%$ & $23.5 \%$ & $51.0 \%$ & $15.7 \%$ & $100.0 \%$ \\
\hline & $30-44$ & $24.0 \%$ & $32.0 \%$ & $12.0 \%$ & $32.0 \%$ & & $100.0 \%$ \\
\hline & 45 to 59 & & $64.7 \%$ & $35.3 \%$ & & & $100.0 \%$ \\
\hline & $\begin{array}{l}\text { More than } \\
60\end{array}$ & & $33.3 \%$ & $66.7 \%$ & & & $100.0 \%$ \\
\hline Total & & $6.0 \%$ & $26.0 \%$ & $23.0 \%$ & $37.0 \%$ & $8.0 \%$ & $100.0 \%$ \\
\hline
\end{tabular}

Again, Table- 6 shows that $75 \%$ of the respondents below 15 years and $76 \%$ of the respondents of age group of 30 years to 44 years strongly agreed that they enjoy the game shows which are sponsored by different superstores. However, 25\% of the respondents of below 5 years, and only $5.9 \%$ of the 
respondents of age group of 45 years to 59 years disagreed to the issue. So it was found that game shows entertained the consumer of all ages of people in more or less extents. So, organization may organize more and more game shows.

Table-6

Age * I enjoyed the games shows which are sponsored by different superstore Crosstabulation

\% within Age

\begin{tabular}{|c|c|c|c|c|c|c|c|}
\hline & \multicolumn{5}{|c|}{$\begin{array}{l}\text { I enjoyed the games shows which are } \\
\text { sponsored by different superstore }\end{array}$} & \multirow[b]{2}{*}{ Total } \\
\hline & & $\begin{array}{l}\text { Strongly } \\
\text { Disagree }\end{array}$ & Disagree & Neutral & Agree & $\begin{array}{l}\text { Strongly } \\
\text { Agree }\end{array}$ & \\
\hline Age & $\begin{array}{l}\text { Below } 15 \\
\text { years }\end{array}$ & & $25.0 \%$ & & & $75.0 \%$ & $100.0 \%$ \\
\hline & 15 to 29 & & $2.0 \%$ & $25.5 \%$ & $31.4 \%$ & $41.2 \%$ & $100.0 \%$ \\
\hline & $30-44$ & & $8.0 \%$ & & $16.0 \%$ & $76.0 \%$ & $100.0 \%$ \\
\hline & 45 to 59 & $5.9 \%$ & & & $70.6 \%$ & $23.5 \%$ & $100.0 \%$ \\
\hline & $\begin{array}{l}\text { More } \\
\text { than } 60\end{array}$ & & $33.3 \%$ & & $66.7 \%$ & & $100.0 \%$ \\
\hline Total & & $1.0 \%$ & $5.0 \%$ & $13.0 \%$ & $34.0 \%$ & $47.0 \%$ & $100.0 \%$ \\
\hline
\end{tabular}

From the Table-7, it was found that free gifts are not very much beneficial to consumers. $75 \%$ of the respondents of below 15 years of age opined themselves neutral in benefit of free gifts offered by marketers. 52\% of respondents of age group from 30 years to 44 years and $33.3 \%$ of respondents of over 60 years of age disagreed to this issue.
Table-7

Age * Free gifts are beneficial for consumers Crosstabulation $\%$ within Age

\begin{tabular}{|c|c|c|c|c|c|c|c|}
\hline & & & ree gifts & are bene & fited fo & me & \\
\hline & & $\begin{array}{l}\text { Strongly } \\
\text { Disagree }\end{array}$ & Disagree & Neutral & Agree & $\begin{array}{l}\text { Strongly } \\
\text { Agree }\end{array}$ & Total \\
\hline Age & $\begin{array}{l}\text { Below } \\
15 \text { years }\end{array}$ & & & $75.0 \%$ & $25.0 \%$ & & 10 \\
\hline & 15 to 29 & $2.0 \%$ & $23.5 \%$ & $17.6 \%$ & $45.1 \%$ & $11.8 \%$ & $100.0 \%$ \\
\hline & $30-44$ & & $52.0 \%$ & $8.0 \%$ & $20.0 \%$ & $20.0 \%$ & $100.0 \%$ \\
\hline & 45 to 59 & $41.2 \%$ & & 35.3\% & & $23.5 \%$ & $100.0 \%$ \\
\hline & $\begin{array}{l}\text { More } \\
\text { than } 60\end{array}$ & & $33.3 \%$ & & $66.7 \%$ & & $100.0 \%$ \\
\hline Total & & $8.0 \%$ & $26.0 \%$ & $20.0 \%$ & $31.0 \%$ & $15.0 \%$ & $100.0 \%$ \\
\hline
\end{tabular}

Table-8: reflects that considering education level, under SSC level, $100 \%$ of the respondents and $50 \%$ of the undergraduate respondents strongly agreed on that CSR activities help consumers to remember the brand afterwards. Conversely, only $40 \%$ of the respondents of HSC level disagreed on the upbeat impact of CSR activities to remember the brand later on. So, it can be concluded that marketers are not fully successful to perform CSR activities like tree plantation, roadside/road divider and/or Island beautification which activities afterward help the consumers to remember the brand for doing positive activities towards the development of the society. 
Table-8

\section{Education * CSR activities are the element to remember} the brand Crosstabulation

\% within Education

\begin{tabular}{|c|c|c|c|c|l|}
\hline \multirow{2}{*}{ Education } & \multicolumn{3}{|c|}{$\begin{array}{c}\text { CSR activities are the element to } \\
\text { remember the brand }\end{array}$} \\
\cline { 2 - 4 } & Disagree & Neutral & Agree & $\begin{array}{l}\text { Strongly } \\
\text { Agree }\end{array}$ & Total \\
\hline SSC & & & & $100.0 \%$ & $100.0 \%$ \\
HSC & $40.0 \%$ & & $40.0 \%$ & $20.0 \%$ & $100.0 \%$ \\
$\begin{array}{l}\text { Under } \\
\text { graduation } \\
\text { Graduation } \\
\text { Others }\end{array}$ & & $2.1 \%$ & $61.7 \%$ & $36.2 \%$ & $100.0 \%$ \\
Total & $2.0 \%$ & $5.0 \%$ & $51.0 \%$ & $42.0 \%$ & $100.0 \%$ \\
\hline \multicolumn{7}{|c|}{ SPSS Output } \\
\hline
\end{tabular}

Table-9 reflects that under education, $95 \%$ of the respondents from SSC level and that of $60 \%$ of HSC level as well as that of $68.1 \%$ of the graduation level strongly agreed on that celebrity endorsement create trustworthiness among consumers about the promise made by the brand. Hence, it is concluded that celebrity endorsement might be attractive to create trustworthiness among consumers.
Table-9

Education * Celebrity endorsement attract me for trustworthiness Crosstabulation

\section{\% within Education}

\begin{tabular}{|c|c|c|c|c|c|c|}
\hline \multirow[b]{2}{*}{ Education } & \multicolumn{5}{|c|}{$\begin{array}{c}\text { Celebrity endorsement attract me for } \\
\text { trustworthiness }\end{array}$} & \multirow[b]{2}{*}{ Total } \\
\hline & $\begin{array}{l}\text { Strongly } \\
\text { Disagree }\end{array}$ & Disagree & Neutral & Agree & $\begin{array}{l}\text { Strongly } \\
\text { Agree }\end{array}$ & \\
\hline SSC & $100.0 \%$ & & & & & $100.0 \%$ \\
\hline HSC & & & $20.0 \%$ & $20.0 \%$ & $60.0 \%$ & $100.0 \%$ \\
\hline Under grad & $3.0 \%$ & $12.1 \%$ & & $42.4 \%$ & $42.4 \%$ & $100.0 \%$ \\
\hline Graduation & & & & $31.9 \%$ & $68.1 \%$ & $100.0 \%$ \\
\hline Others & & & & & $100.0 \%$ & $100.0 \%$ \\
\hline Total & $7.2 \%$ & $4.1 \%$ & $1.0 \%$ & $30.9 \%$ & $56.7 \%$ & $100.0 \%$ \\
\hline & & SPS & Output & & & \\
\hline
\end{tabular}

Table-10 shows that telemarketing is not so much popular at all in Bangladesh. Yet, 54.2\% of respondents of the government employee and $13.9 \%$ of the respondents of students strongly agreed and $56.5 \%$ of the respondents of private employees agreed to the positive impact of telemarketing. However, 13\% respondent of private employees and $11.1 \%$ of the respondents of students disagreed to this matter. So, while companies are using this tool to create consumer awareness and/or to promote a brand, they should be more careful to design the program. 
Table-10

Occupation * Telemarketing helps me keep up to date about product Crosstabulation

\section{\% within Occupation}

\begin{tabular}{|c|c|c|c|c|c|c|}
\hline \multirow[b]{2}{*}{ Occupation } & \multicolumn{5}{|c|}{$\begin{array}{l}\text { Telemarketing helps me keep up to } \\
\text { date about product }\end{array}$} & \multirow[b]{2}{*}{ Total } \\
\hline & $\begin{array}{l}\text { Strongly } \\
\text { Disagree }\end{array}$ & Disagree & Neutral & Agree & $\begin{array}{l}\text { Strongly } \\
\text { Agree }\end{array}$ & \\
\hline Student & $11.1 \%$ & $13.9 \%$ & $50.0 \%$ & $11.1 \%$ & $13.9 \%$ & $100.0 \%$ \\
\hline $\begin{array}{l}\text { Government } \\
\text { employee }\end{array}$ & & $25.0 \%$ & $4.2 \%$ & $16.7 \%$ & $54.2 \%$ & $100.0 \%$ \\
\hline $\begin{array}{l}\text { Private } \\
\text { employee }\end{array}$ & $13.0 \%$ & & $17.4 \%$ & $56.5 \%$ & $13.0 \%$ & $100.0 \%$ \\
\hline Business & & $40.0 \%$ & $13.3 \%$ & $20.0 \%$ & $26.7 \%$ & $100.0 \%$ \\
\hline others & & & & & $100.0 \%$ & $100.0 \%$ \\
\hline Total & $7.0 \%$ & $17.0 \%$ & $25.0 \%$ & $24.0 \%$ & $27.0 \%$ & $100.0 \%$ \\
\hline \multicolumn{7}{|c|}{ SPSS Output } \\
\hline
\end{tabular}

Table- 11 shows $23.2 \%$ of the male respondents and $63.6 \%$ of the female respondents strongly agreed and $73.2 \%$ of the male respondents and $31.8 \%$ of the female respondents agreed on that TV advertisement plays important role as a media to make the brand familiar to the consumers while only $4.5 \%$ of the female respondent disagreed to the issue. Hereby, TV advertisement can be integrated by the marketers to as a promotional tool to make the brand familiar.

\section{Table-11}

Gender * TV advertisement is the best medium to familiar the brand Crosstabulation

\section{$\%$ within Gender}

\begin{tabular}{|ll|l|l|l|l|l|}
\hline \multirow{2}{*}{} & & \multicolumn{3}{|c|}{$\begin{array}{c}\text { TV advertisement is the best medium } \\
\text { to familiar the brand }\end{array}$} & \\
\cline { 3 - 6 } & & $\begin{array}{l}\text { Strongly } \\
\text { Disagree }\end{array}$ & Neutral & Agree & $\begin{array}{l}\text { Strongly } \\
\text { Agree }\end{array}$ & Total \\
\hline Gender & Male & & $3.6 \%$ & $73.2 \%$ & $23.2 \%$ & $100.0 \%$ \\
& Female & $4.5 \%$ & & $31.8 \%$ & $63.6 \%$ & $100.0 \%$ \\
Total & & $2.0 \%$ & $2.0 \%$ & $55.0 \%$ & $41.0 \%$ & $100.0 \%$ \\
\hline \multicolumn{6}{|c|}{ SPSS Output } \\
\hline
\end{tabular}

From the Table-12, it is found that coupon is not reason to buy any product. $35.7 \%$ male respondents and $34.1 \%$ female respondents disagreed to the matter that coupon induces their interest to buy a product. Therefore, it is clear that marketers need to be more careful to design coupon to attract consumers to buy a product.

Table-12

Gender * Coupon induces interest to buy a product Crosstabulation

\% within Gender

\begin{tabular}{|c|l|l|l|l|l|l|}
\hline \multirow{2}{*}{ Gender } & \multicolumn{3}{|c|}{ Coupon induces interest to buy a product } & \multirow{2}{*}{} \\
\cline { 2 - 6 } & $\begin{array}{l}\text { Strongly } \\
\text { Disagree }\end{array}$ & Disagree & Neutral & Agree & $\begin{array}{l}\text { Strongly } \\
\text { Agree }\end{array}$ & Total \\
\hline Male & $8.9 \%$ & $35.7 \%$ & $19.6 \%$ & $26.8 \%$ & $8.9 \%$ & $100.0 \%$ \\
Female & $9.1 \%$ & $34.1 \%$ & $15.9 \%$ & $34.1 \%$ & $6.8 \%$ & $100.0 \%$ \\
Total & $9.0 \%$ & $35.0 \%$ & $18.0 \%$ & $30.0 \%$ & $8.0 \%$ & $100.0 \%$ \\
\hline \multicolumn{7}{|c|}{ SPSS Output } \\
\hline
\end{tabular}


Table- 13 shows that $48.2 \%$ of male respondents and $61.4 \%$ of female respondents strongly agreed and that of $31.2 \%$ of male and $31.8 \%$ of female is agreed to the issue that a positive word of mouth is helpful to create a positive impression of the product in the consumer mind. However, only $3.6 \%$ of the male respondents found it exaggeration about a brand. So, marketers may choose female consumers to express positive word of mouth to their community regarding creating a good impression about their brand. In that case, marketers may also utilize the communal behavior/attitude of the female consumers.

Table-13

Gender * confidence raises about a particular product with a positive word of mouth Crosstabulation

$\%$ within Gender

\begin{tabular}{|c|l|l|l|l|l|}
\hline \multirow{3}{*}{ Gender } & \multicolumn{3}{|c|}{$\begin{array}{c}\text { Confidence raises about a particular } \\
\text { product with a positive word of mouth }\end{array}$} & \multirow{2}{*}{} \\
\cline { 2 - 5 } & \multirow{2}{*}{ Disagree } & Neutral & Agree & $\begin{array}{l}\text { Strongly } \\
\text { Agree }\end{array}$ & Total \\
\hline Male & $3.6 \%$ & $16.1 \%$ & $32.1 \%$ & $48.2 \%$ & $100.0 \%$ \\
Female & & $6.8 \%$ & $31.8 \%$ & $61.4 \%$ & $100.0 \%$ \\
Total & $2.0 \%$ & $12.0 \%$ & $32.0 \%$ & $54.0 \%$ & $100.0 \%$ \\
\hline \multicolumn{6}{|c|}{ SPSS Output } \\
\hline
\end{tabular}

Table- 14 shows that in case of TV advertisement, $55.6 \%$ of respondents from under graduate level and $42.6 \%$ of respondents from graduate level strongly agreed as well as $100 \%$ respondents of SSC level, $80 \%$ respondents of HSC level and $53.2 \%$ respondents of graduate level agreed that TV advertisement is the best medium to make a brand familiar to the consumers. On the contrary, only 5.6\% respondents of under graduate level strongly disagreed to this issue. So, it can be concluded that TV advertisement is the popular form of creating a large positive impact on consumer psychology.

Table-14

Education * TV advertisement is the best medium to familiar the brand Crosstabulation

\section{\% within Education}

\begin{tabular}{|c|c|c|c|c|c|}
\hline \multirow[b]{2}{*}{ Education } & \multicolumn{4}{|c|}{$\begin{array}{l}\text { TV advertisement is the best } \\
\text { medium to familiar the brand }\end{array}$} & \multirow[b]{2}{*}{ Total } \\
\hline & $\begin{array}{l}\text { Strongly } \\
\text { Disagree }\end{array}$ & Neutral & Agree & $\begin{array}{l}\text { Strongly } \\
\text { Agree }\end{array}$ & \\
\hline SSC & \multirow{5}{*}{$5.6 \%$} & \multirow{5}{*}{$4.3 \%$} & $100.0 \%$ & & $100.0 \%$ \\
\hline HSC & & & $80.0 \%$ & $20.0 \%$ & $100.0 \%$ \\
\hline $\begin{array}{l}\text { Under } \\
\text { graduation }\end{array}$ & & & $38.9 \%$ & $55.6 \%$ & $100.0 \%$ \\
\hline Graduation & & & $53.2 \%$ & $42.6 \%$ & $100.0 \%$ \\
\hline Others & & & $100.0 \%$ & & $100.0 \%$ \\
\hline Total & $2.0 \%$ & $2.0 \%$ & $55.0 \%$ & $41.0 \%$ & $100.0 \%$ \\
\hline \multicolumn{6}{|c|}{ SPSS Output } \\
\hline
\end{tabular}

\subsection{Hypothesis Testing}

H0: Coupon does not have a positive influence on customer loyalty.

H1: Coupon does have positive influence on customer loyalty.

From the table-15, the researcher found that H1 Coupon has a positive influence on customer loyalty. Coupon has a positive impact when the incentive of free sample is withdrawn. Here, the $\mathrm{P}$ value $(0.000)$ is less than alpha value (0.05). So, marketers can use the coupon that could have positive impact on loyal customer consumer psychology. 
Table-15

Paired Samples Test: Gender to coupon

\begin{tabular}{|c|c|c|c|c|c|c|c|c|}
\hline & \multicolumn{5}{|c|}{ Paired Differences } & \multirow[b]{3}{*}{$\mathrm{T}$} & \multirow[b]{3}{*}{ df } & \multirow{3}{*}{$\begin{array}{l}\text { Sig. } \\
(2- \\
\text { tailed })\end{array}$} \\
\hline & \multirow[b]{2}{*}{ Mean } & \multirow{2}{*}{$\begin{array}{l}\text { Std. } \\
\text { Deviation }\end{array}$} & \multirow{2}{*}{$\begin{array}{l}\text { Std. } \\
\text { Error } \\
\text { Mean }\end{array}$} & \multicolumn{2}{|c|}{$\begin{array}{l}\text { 95\% Confidence } \\
\text { Interval of the } \\
\text { Difference }\end{array}$} & & & \\
\hline & & & & Lower & Upper & & & \\
\hline $\begin{array}{|ll|}\text { Pair } & \text { Gender } \\
1 & - \\
& \text { Coupon } \\
& \text { is a } \\
& \text { reason } \\
& \text { to buy } \\
& \text { any } \\
& \text { product }\end{array}$ & $\begin{array}{l} \\
1.49000\end{array}$ & 1.25122 & .12512 & $\begin{array}{l} \\
1.73827\end{array}$ & $\begin{array}{l} \\
1.24173\end{array}$ & \begin{tabular}{|l|}
11.908 \\
\end{tabular} & 99 & .000 \\
\hline
\end{tabular}

H0: Online recommendation does not have influence customer loyalty.

H2: Online recommendation does have influence customer loyalty.

Table-16 shows that $\mathrm{H} 2$ stated that online recommendation has influence on customers brand loyalty depending on the age. Here, the $\mathrm{P}$ value (0.004) is less than alpha value (0.05). Thereby, it is concluded that marketers can use online recommendation to create a positive impression on consumer psychology as a less costly medium of marketing activities.
Table-16

Paired Samples Test: Age to online recommendation

\begin{tabular}{|c|c|c|c|c|c|c|c|c|}
\hline & \multicolumn{5}{|c|}{ Paired Differences } & \multirow[b]{3}{*}{$\mathrm{T}$} & \multirow[b]{3}{*}{ df } & \multirow{3}{*}{$\begin{array}{l}\text { Sig. } \\
(2- \\
\text { tailed })\end{array}$} \\
\hline & \multirow[b]{2}{*}{ Mean } & \multirow{2}{*}{$\begin{array}{l}\text { Std. } \\
\text { Deviation }\end{array}$} & \multirow{2}{*}{$\begin{array}{l}\text { Std. } \\
\text { Error } \\
\text { Mean }\end{array}$} & \multicolumn{2}{|c|}{\begin{tabular}{|l|}
$95 \%$ \\
Confidence \\
Interval of \\
the \\
Difference
\end{tabular}} & & & \\
\hline & & & & Lower & Upper & & & \\
\hline $\begin{array}{ll}\text { Pair } & \text { Age - Online } \\
1 & \text { recommendati } \\
& \text { on provides } \\
& \text { details and } \\
& \text { important } \\
& \text { information }\end{array}$ & \begin{tabular}{|l|}
.51000 \\
\end{tabular} & 1.73202 & .17320 & $\begin{array}{l}- \\
.85367\end{array}$ & -16633 & $\begin{array}{l}- \\
2.945\end{array}$ & 99 & .004 \\
\hline
\end{tabular}

H0: Display store does not influence switching the brand.

H3: Display store does influence switching the brand

Table-17 shows that display on the store does have influence on consumer's mind to switch a brand. Here, $P$ value $(0.000)$ is less than alpha value (0.05). So it is clear that display at the store is attractive to impress consumer and consumer are influenced by marketers to switch brand when they find an attractive product at the display. 
Table-17

\section{Paired Samples Test: Education to display at store}

\begin{tabular}{|c|c|c|c|c|c|c|c|c|c|}
\hline & \multicolumn{5}{|c|}{ Paired Differences } & \multirow[b]{3}{*}{$\mathrm{T}$} & & \multirow{3}{*}{\begin{tabular}{|l} 
Sig. \\
$(2-$ \\
tailed $)$
\end{tabular}} \\
\hline & & \multirow[b]{2}{*}{ Mean } & \multirow{2}{*}{$\begin{array}{l}\text { Std. } \\
\text { Deviation }\end{array}$} & \multirow{2}{*}{$\begin{array}{l}\text { Std. } \\
\text { Error } \\
\text { Mean }\end{array}$} & \multicolumn{2}{|c|}{$\begin{array}{l}95 \% \\
\text { Confidence } \\
\text { Interval of the } \\
\text { Difference }\end{array}$} & & & \\
\hline & & & & & Lower & Upper & & $\mathrm{df}$ & \\
\hline $\begin{array}{l}\text { Pair } \\
1\end{array}$ & $\begin{array}{l}\text { Education } \\
\text { - Display } \\
\text { store } \\
\text { attract } \\
\text { consumer } \\
\text { to switch } \\
\text { brands }\end{array}$ & -86000 & 1.21456 & .12146 & 1.10099 & -.61901 & $\begin{array}{l}- \\
7.081\end{array}$ & 99 & .000 \\
\hline
\end{tabular}

H0: Billboard cannot pay easy attention to the specific message of the brand.

H4: Billboard can attract easy attention to the specific message of the brand to consumers.

In the Table-18, it is found the billboard can attract easily attention to the specific message of the brand provided there. Here, the P value (0.000) is also less than alpha value $(0.05)$. Billboard is the most effective way to effect on consumer psychology. It is because when a consumer watches the billboard at their eye level, they easily get the message on billboard.
Table-18

Paired Samples Test: Occupation vs. Billboard

\begin{tabular}{|c|c|c|c|c|c|c|c|c|c|}
\hline & \multicolumn{5}{|c|}{ Paired Differences } & \multirow[b]{3}{*}{$\mathrm{T}$} & \multirow[b]{3}{*}{ df } & \multirow{3}{*}{$\begin{array}{l}\text { Sig. } \\
(2- \\
\text { tailed }\end{array}$} \\
\hline & & \multirow[b]{2}{*}{ Mean } & \multirow{2}{*}{$\begin{array}{l}\text { Std. } \\
\text { Deviatio } \\
n\end{array}$} & \multirow{2}{*}{$\begin{array}{l}\text { Std. } \\
\text { Error } \\
\text { Mean }\end{array}$} & \multicolumn{2}{|c|}{$\mid \begin{array}{l}95 \% \\
\text { Confidence } \\
\text { Interval of the } \\
\text { Difference }\end{array}$} & & & \\
\hline & & & & & Lower & Upper & & & \\
\hline $\begin{array}{l}\text { Pair } \\
1\end{array}$ & $\begin{array}{l}\text { Occupati } \\
\text { on } \\
\text { Billboard } \\
\text { can } \\
\text { easily } \\
\text { attract } \\
\text { attention } \\
\text { to the } \\
\text { specific } \\
\text { message } \\
\text { of the } \\
\text { brand }\end{array}$ & $\begin{array}{l}- \\
2.24000\end{array}$ & 1.23190 & .12319 & $\begin{array}{l}- \\
2.48444\end{array}$ & $\begin{array}{l} \\
1.99556\end{array}$ & $\begin{array}{l}- \\
18.183\end{array}$ & 99 & .000 \\
\hline & & & & $\mathrm{O}$ & & & & & \\
\hline
\end{tabular}

H0: Display in store does not have influence on brand loyalty.

H5: Display in store does have influence on brand loyalty.

Table-19 shows that display in store influence consumers' level of brand loyalty. Display store has positive impact to like a brand and sometimes it might influence to buy a product. Here, the $P$ value $(0.000)$ is less than alpha value $(0.05)$. Thus, it can be concluded that attractive display at store can be eyecatching to impress consumer which might cause impulse buying even. In that case, consumer also might switch to other brand other than their regular preferred brand. 
Table-19

Paired Samples Test: Gender Vs. Display in store

\begin{tabular}{|c|c|c|c|c|c|c|c|c|c|}
\hline & & \multicolumn{5}{|c|}{ Paired Differences } & \multirow{3}{*}{$\mathrm{T}$} & \multirow[b]{3}{*}{ df } & \multirow{3}{*}{$\begin{array}{l}\text { Sig. } \\
(2- \\
\text { taile } \\
\text { d) }\end{array}$} \\
\hline & & \multirow[b]{2}{*}{ Mean } & \multirow{2}{*}{\begin{tabular}{|l|} 
Std. \\
Deviation
\end{tabular}} & \multirow{2}{*}{$\begin{array}{l}\text { Std. } \\
\text { Error } \\
\text { Mean }\end{array}$} & \multicolumn{2}{|c|}{$\begin{array}{l}95 \% \text { Confidence } \\
\text { Interval of the } \\
\text { Difference }\end{array}$} & & & \\
\hline & & & & & Lower & Upper & & & \\
\hline $\begin{array}{l}\text { Pair } \\
1\end{array}$ & $\begin{array}{l}\text { Gender - } \\
\text { Display } \\
\text { store help } \\
\text { consumers } \\
\text { to switch } \\
\text { brands }\end{array}$ & -2.84000 & .91806 & .09181 & -3.02216 & -2.65784 & -30.935 & 99 & .000 \\
\hline \multicolumn{10}{|c|}{ SPSS Output } \\
\hline
\end{tabular}

H0: Leaflet has not a great impact to provide different offer.

H6: Leaflet has a great impact to provide different offer

It is revealed from the Table-20 that leaflet does not have a positive impact to provide sufficient information regarding a brand or does not have relevant impact to catch consumers' attraction towards a brand. Here, $\mathrm{P}$ value $(0.08)$ is greater than alpha value (0.05) which reflects that leaflet is not influential to provide different offer.
Table-20

Paired Samples Test: Occupation vs. leaflet

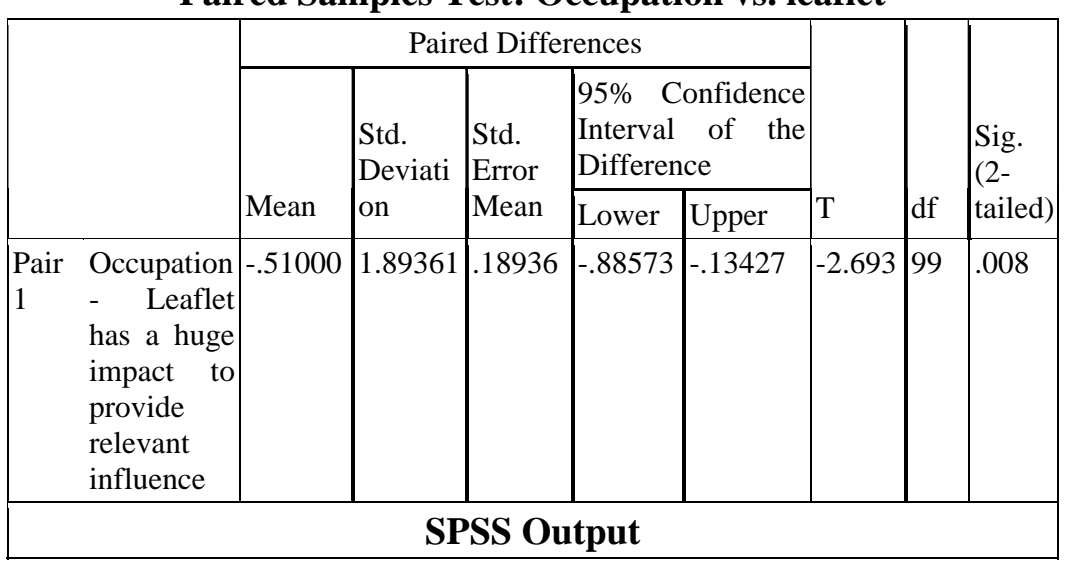

H0: TV advertising is not the best medium to familiar the brand

H7: TV advertising is the best medium to familiar the brand.

It is found in this study that TV advertising is the best medium to make familiar the brand to consumers which is shown in the Table-21. TV advertising has positive impact on consumer psychology. Here the researcher found the $\mathrm{P}$ value is 0.000 which is less than alpha value (0.05). So, it can be wrapped up the companies might use TV advertisement as a strong marketing tool. 
Table-21

Paired Samples Test: Gender Vs. TV advertisement

\begin{tabular}{|c|c|c|c|c|c|c|c|c|}
\hline & \multicolumn{5}{|c|}{ Paired Differences } & \multirow[b]{3}{*}{$\mathrm{t}$} & \multirow[b]{3}{*}{ df } & \multirow{3}{*}{$\begin{array}{l}\text { Sig. } \\
(2- \\
\text { taile } \\
\text { d) }\end{array}$} \\
\hline & \multirow[b]{2}{*}{ Mean } & \multirow{2}{*}{$\mid \begin{array}{l}\text { Std. } \\
\text { Deviati } \\
\text { on }\end{array}$} & \multirow{2}{*}{$\begin{array}{l}\text { Std. } \\
\text { Error } \\
\text { Mean }\end{array}$} & \multicolumn{2}{|c|}{$\begin{array}{l}95 \% \\
\text { Confidence } \\
\text { Interval of } \\
\text { the } \\
\text { Difference }\end{array}$} & & & \\
\hline & & & & $\begin{array}{l}\text { Lowe } \\
\mathrm{r}\end{array}$ & Upper & & & \\
\hline 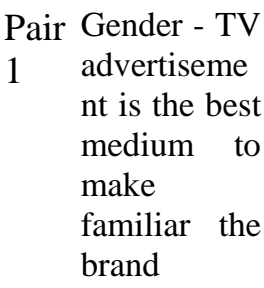 & - & .77714 & .07771 & - & $\begin{array}{l}- \\
2.73580\end{array}$ & - & 99 & .000 \\
\hline & & & $\mathrm{C}$ & but & & & & \\
\hline
\end{tabular}

H0: Demonstration of product does not make good sense of having a fair purchase.

H8: Demonstration of product does make a good sense of having a fair purchase.

From the Table-22, it is found that $\mathrm{P}$ value is 0.00 which is less than alpha value (0.05). It means that demonstration of product before purchase might ensure consumers' confidence on having a good purchase of brand that they are looking for. So marketers can use demonstration of product usage as an attractive way to impress consumer to have that product.
Table-22

Paired Samples Test: Age vs. Product demonstration

\begin{tabular}{|c|c|c|c|c|c|c|c|c|c|}
\hline & \multicolumn{5}{|c|}{ Paired Differences } & \multirow[b]{3}{*}{$\mathrm{t}$} & \multirow[b]{3}{*}{$\mathrm{df}$} & \multirow{3}{*}{$\begin{array}{l}\text { Sig. } \\
(2- \\
\text { tailed })\end{array}$} \\
\hline & & \multirow[b]{2}{*}{ Mean } & \multirow{2}{*}{$\begin{array}{l}\text { Std. } \\
\text { Deviation }\end{array}$} & \multirow{2}{*}{$\begin{array}{l}\text { Std. } \\
\text { Error } \\
\text { Mean }\end{array}$} & \multicolumn{2}{|c|}{\begin{tabular}{|l|}
$95 \%$ \\
Confidence \\
Interval of the \\
Difference
\end{tabular}} & & & \\
\hline & & & & & Lower & Upper & & & \\
\hline $\begin{array}{l}\text { Pair } \\
1\end{array}$ & $\begin{array}{l}\text { Age - } \\
\text { Demonst } \\
\text { ration of } \\
\text { product } \\
\text { ensures } \\
\text { the } \\
\text { feelings } \\
\text { to have } \\
\text { good } \\
\text { purchase }\end{array}$ & $\begin{array}{l}- \\
1.76000\end{array}$ & 1.00624 & .10062 & $\begin{array}{l}- \\
1.95966\end{array}$ & $\begin{array}{l}- \\
1.56034\end{array}$ & -17.491 & 99 & .000 \\
\hline & & & SP & Outp & & & & & \\
\hline
\end{tabular}

\subsection{Correlation among the Variables}

Table-23 shows the correlations among the variables used by the researchers in this study. It is observed from the table that customer loyalty has $29.5 \%$ relation with entertainment where the value is moderate, and $3.6 \%$ correlation with trust and 7.1 $\%$ correlation with perceived value, where it is found that these are positively correlated. Entertainment has $42.9 \%$ correlation with trust, $61.9 \%$ correlation with brand promotion it is strongly correlated and 9.9\% correlation with perceived value. Brand Promotion has correlation 63.2\% correlation (strong positive) with trust, $15.2 \%$ correlation with perceived value. 
Table-23

Correlation among variables

\begin{tabular}{|c|c|c|c|c|c|}
\hline Variables & $\begin{array}{c}\text { Customer } \\
\text { loyalty }\end{array}$ & Entertainment & $\begin{array}{c}\text { Brand } \\
\text { promotion }\end{array}$ & Trust & $\begin{array}{c}\text { Perceived } \\
\text { value }\end{array}$ \\
\hline $\begin{array}{l}\text { Customer } \\
\text { loyalty }\end{array}$ & 1 & & & & \\
\hline Entertainment & .295 & 1 & & & \\
\hline $\begin{array}{l}\text { Brand } \\
\text { promotion }\end{array}$ & .047 & .619 & 1 & & \\
\hline Trust & .036 & .429 & .632 & 1 & \\
\hline $\begin{array}{l}\text { Perceived } \\
\text { value }\end{array}$ & .071 & .099 & -.025 & .152 & 1 \\
\hline \multicolumn{6}{|c|}{ SPSS Output } \\
\hline
\end{tabular}

\section{FINDINGS AND SUGGESTED RECOMMENDATIONS}

\subsection{Findings from the Study}

Following findings were observed from this study:

1. TV advertisement has been found one of the most influential tools to attract and throw out the message regarding a brand to target consumers. This tool helps the consumers to recall the message regarding the brand very quickly because of its visuals and cinematography. It is also found that whenever a real story has been injected to a TV advertisement that people can link up with their experience that works more effectively.

2. Coupon is not found as much as an effective marketing tool. However, it might be effective when it is used instead of free sample. Still organizations may use coupon to deliver a message regarding their brand especially targeting female consumers.
3. Online recommendation now becomes a big trend. People are too much busy with their life today. So, they have little time to go for shopping mall and buy things. But sill roaming and shopping found popular to Bangladeshis. But online recommendations nowadays capture a huge market response.

4. It is found that consumers are very much attracted by display store. When consumer finds a product displayed in the store, a point of sale effect may occur and sometimes consumers make their quick decision to buy the product based on impulse effect. So, marketers may use this technique as a eye catchy way so that it can induce a consumer to have impulse buying.

5. Demonstration of product has also been found to make feel of good sense to the consumers regarding the brand. Consumer found this technique to belief on the good and user friendliness of the product to use. It also increases consumers' level of trustworthiness.

6. Free gifts are found not that much effective to attract the consumer. Rather it was found that it might raise a question regarding the quality of product. So, the marketers should use this technique in a very selective way.

7. Sponsorship may also play a vital role to create a positive impact on consumer mind. A successful event sponsorship by under a brand's title ship create a sense of togetherness among the consumers.

8. SMS marketing has also been found as ineffective marketing techniques. Sometimes people do not even look at the SMS which brings a message related a brand's offer or information. Sometimes they get 
irritating with junk of SMSs from different companies offering different promotion.

9. CSR activities have been found as a good initiative by the organization. Many consumers find it as companies are working together with the environment to save the people and the nature. It also helps them to recall the brand easily for doing positive job towards the society and environment. Consumers also know the brand through this.

10. Female consumers have been found very much attracted by the word of mouth. They feel confident when they listen positive word of mouth and they feel hostile and start gossiping when they hear negative word of mouth. So, in this case, marketers can be tactful to influence female consumers using their communal behavior.

11. Billboard has been found as a very popular form of marketing technique to deliver the message. In the roadside or at a very good visible place has been found very effective to catch the attraction of the consumers. It can grab attention of consumers of any age, gender and occupation.

\subsection{Suggested Recommendations}

This study attempted to understand consumers' psychology regarding marketing activities. From a practical viewpoint, results of this study may provide managers with an insight concerning the potential benefits associated with using marketing activities strategies. Here are some recommendations on marketing strategy depending on the result of the study:
1) Many consumers found free sample as a promotion activity in the very primary stage of the introduction of a brand. However, frequent use of free sample might have negative impact on consumer mind. In some cases consumers' might feel that quality of sample product and original product might vary.

2) A promotional sale is an important tool to win the trust of consumers in the very short run. So marketers should be very careful to offer promotional sales.

3) Marketers should use celebrity or expert people frequently in advertising. This might create a sense among the consumers that the celebrity is doing it for money. However, celebrity endorsement in some extent might be trustworthy to consumers based on quality of brand and level of celerity image.

4) Most of the customers found to either agree or strongly agree to the fact that they think a brand as a personality and thus a brand's reputation exists. So marketers have to maintain the quality of the promised proposition and should increase it with elapse of time and should inject more strong personality relating to their target consumers to the brand to attract the consumer.

5) Billboards should not consist over information and they should be placed where people stuck in traffic jams or find it easily visible. From the viewpoint of culture of Bangladesh and with full respect to it marketers should not too much explicit visuals in the billboard.

\subsection{Conclusions}

Today, consumers' perception has been changed regarding marketers' activities. Now, consumers are much more aware and informed about the brand they have been offered due to open competition in the market. Very personalized communication might be irritating while customerization is 
expected by the consumers. So, this creates a dilemma in the marketers' mind to set their strategic decision. Here, arises the need to understand consumers' psychology to develop their strategic decision after proper understanding and reading consumers' mind. The market is now very much customer oriented. Thus, it is very important for the marketers not only developing a good quality product for their customers but also communicating them in the proper way and of course in better way comparative to their competitors.

Finally, it can be concluded that marketers should focus on understanding consumer psychology to have a deep insight to find out how consumers define their need, want or demand and in which way they want to meet this and how they prefer to be communicated without being irritated and with proper and zeast messages. So, the bottom-line is that marketers should have a clear idea and visuals regarding consumers' psychology to live in today's competitive market without getting hurt by competitors and ultimately which will be helpful for them to increase injecting brand personality in the brand according to consumers' preference.

\section{Bibliography}

Akshay, R. and Monroe, K. R. (1989). "The effect of price, brand name, and store name on buyer's perceptions of product quality: An integrative review", Journal of Marketing Research, Vol. 26, pp. 351-357

Alam, M.S. and Faruqui, M.F. (2009). "Effect of Sales Promotion on Consumer Brand Preference: A Case Study Of Laundry Detergent in Dhaka City Consumers”, ASA University Review, Vol. 3 No. 2.

Apurbo, R.A. ( 2005). “Applied Consumer Psychology”, $1^{\text {st }}$ edition, Pearson Education.
Dzisah, W.E. (2013). “Celebrity Endorsement and Consumer Buying Behavior; Enhancing the Promotion Function of marketing in the Central Business Area of Accra , Ghana", European Journal of Business and Management, Vol. 5 No.25, pp. 197-202.

Familmaleki, M., Aghighi, A. and Hamidi, K. (2000). “Analyzing the Influence of Sales Promotion on Customer Purchasing Behavior", International Journal of Economics \& Management Sciences, Vol. 4 No. 23.

Foxall, G.R., Goldsmith, R.E. and Brown, S. (1998). "Consumer Psychology about Marketing”, $2^{\text {nd }}$ edition, British Library Cataloging in publication data.

Kotler, P. and Keller, K. L. (2009). “ Marketing Management”, $13^{\text {th }}$ edition, Prentice Hall, NJ.

Malhotra N. K. (2008), "Marketing Research - An Applied Orientation", ( $5^{\text {th }}$ edn.), Pearson Education Limited

Moorthy, S. and Hawkins, S.A. (2005). "Advertising repetition and quality perception”, Journal of Business Research, Vol. 58, pp. 354- 360.

Mughal, A., Mehmood, A., Mohi-ud-deen, A. and Ahmed, B. (2014). "The Impact of Promotional Tools on Consumer Buying Behavior: A Study from Pakistan”, Journal of Public Administration and Governance, Vol 4 No. 3, pp. 404-408

Neha, S. (2013). "Impact of Sales Promotion Tools on Consumer's Purchase Decision towards White Good (Refrigerator) at Durg and Bhilai Region of CG, India', Research Journal of Management Sciences, Vol 2(7), pp. 10-11.

Okoroafo, S.C. (2009). "The Impact of the Marketing Activities of Family Owned Businesses on Consumer Purchase Intentions”, International Journal of Business and Management, Vol.4 No.10.

Papagiannidis, S., Bourlakis, M., Woerndl, M. and Li, F. (2008). "Internet-induced marketingtechniques: Critical factors in viral 
marketing campaigns”, Int. Journal of Business Science and Applied Management, Vol. 3. No1.

Paquette, H. (2013). "Social Media as a Marketing Tool: A Literature Review".

Rizwan, M., Javed, M.A. and Khan, M.T. (2008). "The Impact of Promotional Tools on Consumer Buying Behavior: A Study from Pakistan”, Asian Journal of Empirical Research , Vol 3(2), pp. 118-134.

Sandra, J., Dalia, S. and Narbutas, V. (2008). "The Psychological Impact of Advertising on the Customer Behavior", Communications of the IBIMA, Vol. 3.

Shallu, M. and Gupta, S. ( 2013). "Impact of Promotional Activities on Consumer Buying Behavior: A Study of Cosmetic Industry", International Journal of Commerce, Business and Management (IJCBM), Vol 2. No 6, pp. 379-381.

Yolanda, F., Sese, J. and Verhoef, P. C. (2011). "The Effect of Pricing and Advertising on Customer Retention in a Liberalizing Market”, Journal of Interactive Marketing, Vol. 25, pp. 201-214. 